\title{
Advances in murine models of breast cancer bone disease
}

\author{
Penelope D. Ottewell, Michelle A. Lawson \\ Department of Oncology and Metabolism, Mellanby Centre for Bone Research, University of Sheffield, Sheffield S10 2RX, UK.
}

Correspondence to: Dr. Penelope D. Ottewell, Department of Oncology and Metabolism, Mellanby Centre for Bone Research, University of Sheffield, Sheffield S10 2RX, UK. E-mail: p.d.ottewell@sheffield.ac.uk

How to cite this article: Ottewell PD, Lawson MA. Advances in murine models of breast cancer bone disease. J Cancer Metastasis Treat 2021;7:11. https://dx.doi.org/10.20517/2394-4722.2021.14

Received: 22 Jan 2021 First Decision: 10 Feb 2021 Revised: 24 Feb 2021 Accepted: 26 Feb 2021 Published: 8 Mar 2021

Academic Editor: Lucio Miele Copy Editor: Yue-Yue Zhang Production Editor: Yue-Yue Zhang

\begin{abstract}
Bone is the most prevalent metastatic site for breast cancer affecting $~ 70 \%$ of patients with late-stage disease. Treatments for this condition currently focus on controlling disease progression and limiting tumour-induced damage to bone, thereby playing a valuable role in increasing quality of life. However, limited understanding of the interplay between tumour cells and their environment during bone metastasis has impeded the development of curative treatments. To unravel the complex genetic and phenotypic alterations that occur during this process, it would be helpful to have a model in which tumours develop spontaneously at the primary site, spread to bone, undergo a dormancy phase and then, after a fixed timeframe, become re-activated to form osteolytic/mixed lesions in the skeleton. Unlike humans, spontaneous metastasis of primary mammary tumours to bone is rare in mice and no syngeneic models of oestrogen receptor positive disease have been reported. As there is no single model that authentically reproduces all of the genetic and phenotypic changes representative of human bone metastasis, this review discusses the traditional and novel mouse models that are used to study bone metastasis from breast cancer. Additionally, this review focuses on advances that have been made towards making these models more closely related to human disease in an attempt to help researchers select the correct model(s) for their experimental needs with the aim of improving translational efficacy between the laboratory and the clinic.
\end{abstract}

Keywords: Breast cancer, bone metastasis, mouse models 


\section{INTRODUCTION}

Bone is a common metastatic site for breast cancer and is most prevalent from oestrogen receptor (ER)positive disease ${ }^{[1]}$. Once in bone, cancers are currently considered to be incurable and life expectancy for patients' drops to just 2-4 years following diagnosis of bone involvement ${ }^{[2]}$. It is therefore imperative that researchers better understand the mechanisms that drive the different stages of the bone metastatic process to enable development of more effective and curative therapies.

Metastasis is a complex, multistep process involving genetic and phenotypic changes in tumour cells and cells within the local environment. In addition, evidence suggests that signalling between tumour cells and bone cells is an early event, in which tumour cells at the primary site produce microRNAs and other secreted factors, such as Lysyl oxidase and interleukin 1 beta, that prime bone for receiving metastatic cells and in return bone cells secrete chemo attractants that promote tumour cell homing to this site ${ }^{[3-6]}$. The complex nature of this process necessitates the use of whole-body organisms. However, unlike humans, spontaneous metastasis of primary mammary tumours to bone is rare in mice and no syngeneic models of ER-positive disease have been reported. To date, there is no single model that authentically reproduces all of the genetic and phenotypic changes representative of human bone metastasis, therefore researchers must select the most appropriate model(s) to test their hypotheses. In this review, we discuss the traditional and novel mouse models that are used to study bone metastasis from breast cancer, focusing on advances that have been made towards making these models more closely related to human disease in an attempt to improve translational efficacy between the laboratory and the clinic.

\section{BREAST CANCER BONE METASTASIS; WHAT ARE WE TRYING TO MODEL?}

Seventy to eight per cent of patients with late-stage breast cancer will develop bone metastasis and the majority of these patients will have ER-positive disease ${ }^{[1]}$. Dissemination of tumour cells into bone is believed to be an early event, often occurring before clinical detection of the primary tumour. However, overt metastases do not usually develop until many years later ${ }^{[1]}$. When tumour cells arrive in the bone microenvironment, they home to the bone metastatic niche (comprised of the endosteal/haematopoietic stem cell and peri-vascular niches) ${ }^{[7,8]}$. Interactions between tumour cells and the niche(s) promote tumour cell dormancy and/or metastatic outgrowth, dependent upon a number of factors including tumour volume, stage, molecular sub-type and environmental conditions. Typically, ER-negative tumours display a more aggressive phenotype with disease recurrence peaking around two years after diagnosis and relapse rate reducing to low levels $>5$ years after diagnosis. Whereas less aggressive ER-positive breast cancer has a long latency, with low risk of recurrence in the initial five years after diagnosis, the risk of recurrence increasing annually after five years following both diagnosis and surgical removal of the primary tumour ${ }^{[9]}$. Interestingly, the 15-year recurrence is similar in both ER-negative and ER-positive disease, suggesting that both molecular subtypes contain a population of cells capable of undergoing long-term dormancy in bone ${ }^{[10]}$. It is believed that long periods of latency associated with bone metastasis are due to disseminated tumour cells either needing time to alter their new environment to enable increased metastatic outgrowth of tumour cells through expansion of the metastatic niche(s)/suppression of immune regulation or waiting until external factors alter the local microenvironment in a manner that promotes tumour growth. Once tumour cells begin to outgrow into overt metastasis in bone, they stimulate increased resorption of the bone matrix, through receptor activator of nuclear factor $\kappa \mathrm{B}(\mathrm{RANK}) / \mathrm{RANK}$ ligand (RANKL)-induced activation of osteoclasts, resulting in the formation of osteolytic lesions in the affected bone and release of matrix-bound cytokines, including interleukin 6 (IL-6) and tumour necrosis factor alpha (TNF $\alpha$ ), which feedback onto the tumour cells further stimulating their growth. These interactions between tumour cells and bone cells cause a positive feedback loop known as the vicious cycle of bone metastasis (reviewed $\left.\mathrm{in}^{[11,12]}\right)$. It must be noted, however, that bone metastases from breast cancers are not exclusively 
osteolytic, and secretion of growth factors including epidermal growth factors, bone morphogenic proteins and platelet derived growth factors from tumour cells increase osteoblast activity, resulting in the production of mixed lesions which can be observed in a subset of patients (reviewed $\operatorname{in}^{[13]}$ ).

Breast cancer bone metastasis is a complex process involving many signalling pathways and cell types, and there are potentially variations in mechanisms that drive metastasis from different molecular sub-types. Because of this complexity, a variety of in vivo mouse models has been developed to allow researchers to investigate specific aspects of this disease process.

\section{MOUSE MODELS}

\section{Human breast cancer xenograft models}

To facilitate growth of human breast cancer cells in a different species, such as mouse, it is essential to use an immunodeficient host. The majority of human breast cancer cells lines that are either trophic to the bone environment or form overt tumours following injection directly into bone grow readily in nude mice that have been bred on a BALB/c or MF1 background [Table 1] ${ }^{[14-19]}$. These mice have no thymus and therefore cannot generate mature $\mathrm{T}$ lymphocytes and are unable to mount many types of adaptive immune responses including graft rejection ${ }^{[20]}$. Some, more difficult to culture cell lines as well as patient derived xenografts (PDXs) will only graft/grow in more severely immunocompromised mice. For these models, NOD SCID mice that have severe immunodeficiency affecting $\mathrm{T}$ and $\mathrm{B}$ lymphocyte development as well as having reduced NK cells, macrophages and granulocytes numbers and functionality can be utilized ${ }^{[21-23]}$. There has been a recent trend amongst researchers to move towards the use of even more severely immunocompromised, NOD SCID $\Upsilon$ (NSG) mice, for grafting PDXs, as these animals are deficient in multiple cytokine signalling pathways as well as those seen in NOD SCID mice increasing the likelihood of successful tumour engraftment ${ }^{[2,24]}$. Because immune response has profound effects on tumorigenesis and the activity of many anti-cancer agents [Table 2], data obtained from these models must be interpreted cautiously.

\section{Immortalised breast cancer cell lines}

Injecting human bone trophic breast cancer cell lines into the blood stream of young (4-8 weeks old) mice is the most commonly used model for generating bone metastases in the laboratory. This method is useful for investigating tumour cell homing, colonisation, metastatic outgrowth and associated interactions with the bone microenvironment as well as therapeutics. Injection of human triple negative, MDA-MB-231, or ERpositive, MCF7, cells into the left cardiac ventricle or carotid artery in appropriate mouse strains results in tumour growth in the long bones spine and jaw [Table 1$]^{[6,14,16,17,25]}$. This method works particularly well with MDA-MB-231 cells from which osteolytic tumours develop in 60\%-90\% of animals 2-4 weeks following injection. Bone metastasis from MCF7 cells form mixed (lytic/blastic) lesions, however these occur less frequently, over an extended time period (20-25 weeks) and often require oestradiol supplementation ${ }^{[26]}$. Data showing bone metastases from intra-cardiac injection of other human breast cancer cell lines are lacking, suggesting that this is an infrequent event. The high propensity of MDA-MB-231 cells to metastasise to bone following intra-cardiac injection has resulted in this becoming the model of choice for many researchers, but this model is not without its limitations:

- The majority of bone metastasis from breast cancers, in humans, occur from ER-positive rather than ERnegative disease represented by MDA-MB-231 cells.

- Bone metastasis is associated with tumour cells, from the primary site, homing to specific metastatic niches in bone and undergoing long periods of dormancy in these sites before outgrowth into overt metastasis. The 
Table 1. Summary of immune compromised mouse models of breast cancer bone metastasis

\begin{tabular}{|c|c|c|c|c|c|c|}
\hline Cell line & Origin & Sub-line & Model system & Inoculation route & Metastatic site & Lesion \\
\hline \multirow[t]{7}{*}{$\begin{array}{l}\text { MDA- } \\
\text { MB-231 }\end{array}$} & \multirow{7}{*}{$\begin{array}{l}\text { Human } \\
\text { mammary } \\
\text { adenocarcinoma } \\
\text { isolated from a } \\
\text { pleural effusion }\end{array}$} & \multirow{3}{*}{$\begin{array}{l}\text { Parental } \\
\text { (ER-PR-HER2-) }\end{array}$} & \multirow{3}{*}{$\begin{array}{l}\text { BALB/c nude } \\
\text { MF1 nude } \\
\text { NOD SCID } \\
\text { NSG }\end{array}$} & Intra-cardiac & $\begin{array}{l}\text { Mouse long bones, } \\
\text { spine and jaw }\end{array}$ & Osteolytic 2-3 weeks \\
\hline & & & & Intra-tibial & Mouse tibiae & Osteolytic 1-2 weeks \\
\hline & & & & Orthotopic (MIND) & Human bone $\mathrm{x}$-plants & Osteolytic 4-7 weeks \\
\hline & & \multirow{2}{*}{$\begin{array}{l}\text { MDA-MB-231- } \\
\text { BO2 } \\
\text { (ER-PR-HER2-) }\end{array}$} & \multirow[t]{2}{*}{ BALB/c nude } & $\begin{array}{l}\text { Intra-cardiac } \\
\text { Intra-arterial }\end{array}$ & $\begin{array}{l}\text { Mouse long bones, } \\
\text { spine and jaw }\end{array}$ & Osteolytic 2-3 weeks \\
\hline & & & & Intra-tibial & Mouse tibiae & Osteolytic 1-2 weeks \\
\hline & & \multirow[t]{2}{*}{$\begin{array}{l}\text { MDA-MB-231-IV } \\
\text { (ER-PR-HER2-) }\end{array}$} & BALB/c nude & $\begin{array}{l}\text { Intra-cardiac } \\
\text { Intra-arterial } \\
\text { Intra-venous }\end{array}$ & $\begin{array}{l}\text { Mouse long bones, } \\
\text { spine }\end{array}$ & Osteolytic 2-3 weeks \\
\hline & & & NOD SCID & Orthotopic (MIND) & Human bone X-plants & Osteolytic 4-7 weeks \\
\hline $\begin{array}{l}\text { MDA- } \\
\text { MB-436 }\end{array}$ & $\begin{array}{l}\text { Human } \\
\text { mammary } \\
\text { adenocarcinoma } \\
\text { isolated from a } \\
\text { pleural effusion }\end{array}$ & $\begin{array}{l}\text { Parental } \\
\text { (ER-PR-HER2-) }\end{array}$ & $\begin{array}{l}\text { MF1 nude } \\
\text { BALB/c nude } \\
\text { NOD SCID }\end{array}$ & Intra-tibial & Mouse tibiae & Osteolytic 2-3 weeks \\
\hline \multirow{2}{*}{$\begin{array}{l}\text { SUM- } \\
1315\end{array}$} & \multirow{2}{*}{$\begin{array}{l}\text { Isolated from a } \\
\text { metastatic } \\
\text { nodule from } \\
\text { ductal } \\
\text { carcinoma }\end{array}$} & \multirow{2}{*}{$\begin{array}{l}\text { Parental } \\
\text { (ER-PR-HER2-) }\end{array}$} & \multirow[t]{2}{*}{ NOD SCID } & Orthotopic (fat pad) & Human bone X-plants & Osteolytic 4-8 weeks \\
\hline & & & & Intra-tibial & Mouse tibiae & Osteolytic 3-4 weeks \\
\hline \multirow[t]{6}{*}{ MCF-7 } & \multirow{6}{*}{$\begin{array}{l}\text { Human } \\
\text { mammary } \\
\text { adenocarcinoma } \\
\text { isolated from a } \\
\text { pleural effusion }\end{array}$} & \multirow{4}{*}{$\begin{array}{l}\text { Parental } \\
\text { (ER+PR+HER2-) } \\
\text { under estradiol } \\
\text { supplementation }\end{array}$} & \multirow[t]{3}{*}{ BALB/c nude } & Intra-cardiac & Mouse long bones & Mixed $20-25$ weeks \\
\hline & & & & Intra-tibial & Mouse tibiae & Mixed 1-3 weeks \\
\hline & & & & Orthotopic (fat pad) & Mouse long bones & Mixed 4-6 weeks \\
\hline & & & NOD SCID & Orthotopic (fat pad) & $\begin{array}{l}\text { Mouse long bones } \\
\text { Human X-plants }\end{array}$ & Mixed 6-8 weeks \\
\hline & & \multirow[t]{2}{*}{ MCF-7/Neu } & \multirow[t]{2}{*}{ BALB/c nude } & Intra cardiac & Mouse long bones & Mixed $10-12$ weeks \\
\hline & & & & Intra tibial & Mouse long bones & Mixed 1-3 weeks \\
\hline \multirow[t]{4}{*}{ T47D } & \multirow{4}{*}{$\begin{array}{l}\text { Human } \\
\text { mammary } \\
\text { ductal } \\
\text { carcinoma } \\
\text { isolated from a } \\
\text { pleural effusion }\end{array}$} & \multirow{4}{*}{$\begin{array}{l}\text { Parental } \\
\text { (ER+PR+HER2+) } \\
\text { under estradiol } \\
\text { supplementation) }\end{array}$} & \multirow{3}{*}{ BALB/c nude } & Intra-cardiac & Mouse long bones & Mixed $20-25$ weeks \\
\hline & & & & Intra-tibial & Mouse tibiae & Mixed 1-3 weeks \\
\hline & & & & Orthotopic (fat pad) & Mouse long bones & Mixed 4-6 weeks \\
\hline & & & NOD SCID & Orthotopic (fat pad) & $\begin{array}{l}\text { Mouse long bones } \\
\text { Human X-plants }\end{array}$ & Mixed 6-8 weeks \\
\hline ZR75-1 & $\begin{array}{l}\text { Human ductal } \\
\text { carcinoma } \\
\text { derived from a } \\
\text { malignant } \\
\text { ascitic effusion }\end{array}$ & $\begin{array}{l}\text { Parental } \\
(E R+P R+E R 2+)\end{array}$ & BALB/c nude & Intra-cardiac & $\begin{array}{l}\text { Mouse long bones and } \\
\text { spine }\end{array}$ & Mixed $12-25$ weeks \\
\hline \multirow{6}{*}{$\begin{array}{l}\text { Patient } \\
\text { derived } \\
\text { xenograft } \\
\text { (PDX) }\end{array}$} & \multirow{2}{*}{$\begin{array}{l}\text { Human ductal } \\
\text { carcinoma } \\
\text { created from } \\
\text { primary breast } \\
\text { tumour }\end{array}$} & \multirow[t]{2}{*}{$\begin{array}{l}\text { BB2RC08 } \\
\text { (ER+PR+HER2-) } \\
\text { Under estradiol } \\
\text { supplementation }\end{array}$} & \multirow[t]{2}{*}{ NSG } & Orthotopic (MIND) & $\begin{array}{l}\text { Mouse long bones, } \\
\text { lungs and human bone } \\
\text { X-plants }\end{array}$ & Lytic $14+$ weeks \\
\hline & & & & Intra-cardiac & $\begin{array}{l}\text { Mouse long bones, } \\
\text { lungs and human bone } \\
\text { X-plants }\end{array}$ & Lytic $14+$ weeks \\
\hline & \multirow{2}{*}{$\begin{array}{l}\text { Human ductal } \\
\text { carcinoma } \\
\text { isolated from } \\
\text { ascitic fluid }\end{array}$} & \multirow{2}{*}{$\begin{array}{l}\text { BB3RC32 } \\
\text { (ER+PR+HER2-) } \\
\text { Under estradiol } \\
\text { supplementation }\end{array}$} & \multirow[t]{2}{*}{ NSG } & Orthotopic (MIND) & $\begin{array}{l}\text { Mouse long bones, } \\
\text { lungs and human bone } \\
\text { X-plants }\end{array}$ & Lytic $15+$ weeks \\
\hline & & & & Intra-cardiac & $\begin{array}{l}\text { Mouse long bones, } \\
\text { lungs and human bone } \\
\text { X-plants }\end{array}$ & Lytic $15+$ weeks \\
\hline & \multirow{2}{*}{$\begin{array}{l}\text { Human ductal } \\
\text { carcinoma } \\
\text { created from } \\
\text { primary breast } \\
\text { tumour }\end{array}$} & \multirow{2}{*}{$\begin{array}{l}\text { BB6RC37 } \\
\text { (ER-PR-HER2-) } \\
\text { Under estradiol } \\
\text { supplementation }\end{array}$} & \multirow[t]{2}{*}{ NSG } & Orthotopic (MIND) & $\begin{array}{l}\text { Mouse long bones, } \\
\text { lungs and human bone } \\
\text { X-plants }\end{array}$ & Lytic $12+$ weeks \\
\hline & & & & Intra-cardiac & $\begin{array}{l}\text { Mouse long bones, } \\
\text { lungs and human bone } \\
\text { X-plants }\end{array}$ & Lytic $15+$ weeks \\
\hline
\end{tabular}

short duration between injection of MDA-MB-231 cells and metastatic outgrowth indicates a lack of 
Table 2. Summary of immune competent mouse models of breast cancer bone metastasis

\begin{tabular}{|c|c|c|c|c|c|c|}
\hline $\begin{array}{l}\text { Cell } \\
\text { line }\end{array}$ & Origin & Sub-line & Model system & Inoculation route & Metastatic site & Lesion \\
\hline \multirow[t]{6}{*}{$4 \mathrm{~T} 1$} & \multirow{6}{*}{$\begin{array}{l}\text { Mouse isolated } \\
\text { from stage } 1 \mathrm{~V} \\
\text { mammary } \\
\text { tumour from a } \\
\text { female BALB/c } \\
\text { cfC } 3 \mathrm{H} \text { mouse }\end{array}$} & \multirow{3}{*}{$\begin{array}{l}\text { Parental } \\
\text { (ER-PR- } \\
\text { HER2-) }\end{array}$} & \multirow[t]{3}{*}{$\mathrm{BALB} / \mathrm{c} \mathrm{cfC} 3 \mathrm{H}$} & Intra-cardiac & $\begin{array}{l}\text { Mouse long bones, spine, } \\
\text { jaw, lungs and spleen }\end{array}$ & Osteolytic 2-3 weeks \\
\hline & & & & $\begin{array}{l}\text { Orthotopic (fat } \\
\text { pad/MIND) }\end{array}$ & $\begin{array}{l}\text { Mouse long bones, spine, } \\
\text { jaw, lungs and spleen }\end{array}$ & Osteolytic 3-4 weeks \\
\hline & & & & Intra-osseous & Recipient bone & Osteolytic 1-3 weeks \\
\hline & & \multirow{3}{*}{$\begin{array}{l}4 T 1-2 \\
\text { (ER-PR- } \\
\text { HER2-) }\end{array}$} & \multirow[t]{3}{*}{$\mathrm{BALB} / \mathrm{c} \mathrm{cfC} 3 \mathrm{H}$} & Intra-cardiac & $\begin{array}{l}\text { Mouse long bones, spine, } \\
\text { jaw, lungs and spleen }\end{array}$ & Osteolytic 2-3 weeks \\
\hline & & & & Orthotopic (fat pad) & $\begin{array}{l}\text { Mouse long bones, spine, } \\
\text { jaw, lungs and spleen }\end{array}$ & Osteolytic 3-4 weeks \\
\hline & & & & Intra-osseous & Recipient bone & Osteolytic 1-3 weeks \\
\hline \multirow[t]{2}{*}{$\begin{array}{l}\text { PyMT } \\
\text { MMTV }\end{array}$} & \multirow{2}{*}{$\begin{array}{l}\text { Isolated from a } \\
\text { mammary } \\
\text { tumour induced } \\
\text { by MMTV viral } \\
\text { oncogene in an } \\
\text { PVB/N female } \\
\text { mouse }\end{array}$} & \multirow{2}{*}{$\begin{array}{l}\text { Parental } \\
\text { (ER-PR- } \\
\text { HER2-) }\end{array}$} & \multirow[t]{2}{*}{$\mathrm{FVB} / \mathrm{N}$} & Intra-cardiac & $\begin{array}{l}\text { Mouse long bones, spine } \\
\text { jaw and lungs }\end{array}$ & Osteolytic 2-3 weeks \\
\hline & & & & Intra-osseous & Recipient bone & Osteolytic 1-2 weeks \\
\hline \multirow[t]{2}{*}{ E0771 } & \multirow{2}{*}{$\begin{array}{l}\text { Medullary } \\
\text { breast } \\
\text { adenocarcinoma } \\
\text { isolated from a } \\
\text { spontaneous } \\
\text { tumour in a } \\
\text { female C57BL/6 } \\
\text { mouse }\end{array}$} & \multirow{2}{*}{$\begin{array}{l}\text { Parental } \\
\text { (ER-PR- } \\
\text { HER2-) }\end{array}$} & \multirow[t]{2}{*}{$\mathrm{C} 57 \mathrm{BL} / 6$} & $\begin{array}{l}\text { Intra-cardiac } \\
\text { Intra-tibial }\end{array}$ & $\begin{array}{l}\text { Mouse long bones, spine } \\
\text { jaw and lungs }\end{array}$ & Mixed 2-3 weeks \\
\hline & & & & Orthotopic (MIND) & $\begin{array}{l}\text { Mouse long bones, spine } \\
\text { jaw and lungs }\end{array}$ & Osteolytic 1-3 weeks \\
\hline \multirow[t]{2}{*}{ Py8119 } & \multirow{2}{*}{$\begin{array}{l}\text { Obtained from } \\
\text { spontaneously } \\
\text { arising tumours } \\
\text { in MMTV- } \\
\text { PyMY } \\
\text { transgenic } \\
\text { C57BL/6 female } \\
\text { mice }\end{array}$} & \multirow{2}{*}{$\begin{array}{l}\text { Parental } \\
\text { (ER-PR- } \\
\text { HER2) }\end{array}$} & \multirow[t]{2}{*}{$\mathrm{C} 57 \mathrm{BL} / 6$} & $\begin{array}{l}\text { Intra-cardiac } \\
\text { Intra-tibial }\end{array}$ & $\begin{array}{l}\text { Mouse long bones, spine, } \\
\text { lungs and jaw }\end{array}$ & Mixed 2-3 weeks \\
\hline & & & & Orthotopic (MIND) & Mouse tibiae & Mixed 1-3 weeks \\
\hline \multirow[t]{3}{*}{ KEP } & \multirow{3}{*}{$\begin{array}{l}\text { Mouse invasive } \\
\text { lobular } \\
\text { carcinoma } \\
\text { derived from a } \\
\text { Keratin14- } \\
\text { driven E- } \\
\text { cadherin/p53 } \\
\text { (KEP) knock out } \\
\text { mammary } \\
\text { carcinoma }\end{array}$} & \multirow{3}{*}{$\begin{array}{l}\text { PKEP/Luc } \\
\text { (ER-PR- } \\
\text { HER2-) }\end{array}$} & \multirow{3}{*}{$\begin{array}{l}\text { IL2R } \gamma \mathrm{C}-/- \\
\text { RAG -/- } \\
\text { BALB/C }\end{array}$} & Intra-cardiac & Mouse long bones & Osteolytic 2-4 weeks \\
\hline & & & & Orthotopic & Spine & Osteolytic 3-5 weeks \\
\hline & & & & Orthotopic & $\begin{array}{l}\text { Mouse long bones and } \\
\text { spine }\end{array}$ & Osteolytic 6-9 weeks \\
\hline
\end{tabular}

dormancy phase in this model.

- Bone metastases from parental MDA-MB-231 cells occur randomly (not always in the long bones), resulting in large $n$ numbers being required for analysis.

- Intra-cardiac injection requires considerable technical expertise, and even with this $\sim 10 \%$ of mice die of stroke, due to cells becoming stuck in the circulation, or develop hind limb paralysis resulting in undesirable loss of animals.

- The requirement for immune-compromised mice prevents accurate representation of immune response to tumours/therapies. 
Considerable amounts of research are therefore being carried out to produce alternative models that can be used to answer questions that are less suited to the traditional, MDA-MB-231, intracardiac model. Indeed, ER-positive MCF7 and T47D models that display long latency may be more representative of human disease and may prove to be useful for investigating efficacy of treatments on mixed lesions, as this phenotype is not commonly investigated in mouse models but is observed in a subset breast cancer patients $^{[27]}$. With careful selection of the appropriate model systems researchers now have a fairly comprehensive tool set for investigating various aspects of breast cancer bone metastasis [Table 1].

(1) Improving outcome, frequency and molecular subtypes represented in mouse models of breast cancer bone metastases

To increase the frequency of bone metastases and reduce the need for intra-cardiac injections, bone seeking sub-lines of MDA-MB-231 cells have been produced via repeated in vivo passaging through mouse bones $^{[7,15,19,28]}$; MDA-MB-231-B02, MDA-MB-231-B and MDA-MB-231-bone cells form tumours in up to $90 \%$ of mice following injection into the caudal artery, whereas MDA-IV cells form tumours in $80 \%-90 \%$ of mice after injection into the lateral tail vein ${ }^{[7,15,1,28-31]}$. Via a similar mechanism, of in vivo passaging, researchers have also produced a bone seeking MCF7 breast cancer cell line that predominantly forms osteolytic lesions after 10-12 weeks ${ }^{[26]}$. Recently, researchers have reported high incidences of bone metastasis from ER-positive MCF7 cells following injection via the caudal artery without the need for oestradiol supplementation, suggesting that this method may be useful for modelling bone metastases from a wide variety of breast cancer subtypes ${ }^{[25]}$. Injecting tumour cells via the caudal artery/tail vein appears to result in bone metastases primarily forming in the hind limbs, simplifying downstream analysis and allowing reduced numbers of animals to be used for statistical analysis. Importantly, these methods are not associated with stroke or early hind limb paralysis, reducing risks of adverse events that are commonly observed following intra-cardiac injection.

Many breast cancer cell lines do not form bone metastases following injection into the blood stream. For the majority of these, bone metastases can be modelled by direct injection into the tibia or femur, which results in the development of osteolytic tumours in the corresponding bone. This method has successfully been used to model interactions between the bone microenvironment and tumour cells and has shown efficacy as a method for xenografting ER-negative MDA-MB-231, MDA-MB-436 and SUM 1315 cells as well as PDXs and ER-positive MCF7 or T47D cells following oestradiol supplementation ${ }^{[32-36]}$. This method has the advantage of high tumour take rates in bone and is useful for studying genetic manipulation of the host/tumour cell environment. However, intra-osseous injection results in considerable damage to the bone cortex and displaces cells within the marrow cavity promoting increased cytokine release and bone turnover during the healing process; these factors must be taken into account when analysing data acquired using this method. Furthermore, intra-osseous injection bypasses the early stages of metastasis including homing to the bone microenvironment and tumour cells do not need to interact with the bone metastatic niche from which bone metastases normally develop. Intra-osseous injection cannot therefore be used to model tumour cell dormancy or early stages of metastases.

(2) Modelling bone homing with human breast cancer xenografts

Injection of breast cancer cells into the left cardiac ventricle or caudal artery results in tumour cells being disseminated into the skeleton via the arterial system. It has been argued that these cells do not home to bone; instead, tumour cells become trapped in the capillaries, from which they then migrate to the metastatic niche(s). Therefore, this is not an appropriate model for investigating mechanisms associated 
with bone homing ${ }^{[15]}$. Injection into the lateral tail vein may better model bone homing, as tumour cells introduced into the venous circulation in this manner need to make at least one pass through the circulatory system before being disseminated in bone. Indeed, introduction of most cell lines into the lateral tail vein results in tumour growth in the lungs and only cells "homed" to bone produce bone metastases with this $\operatorname{method}^{[37]}$. However, studies comparing specific molecular profiles of MDA-MB-231 cells that for form bone metastases following intra-cardiac injection (MDA-MB-231-B02) and clones of MDA-MB-231 cells that form bone metastasis following intra-venous injection (MDA-MB-231-IV) have demonstrated that both of these clones show bone homing profiles and that these clones are more closely related to each other than to the parental clone ${ }^{[1,19,30]}$. Furthermore, intra-cardiac and intra-venous injection of bone homing clones of MDA-MB-231 cells results in tumour cell dissemination into the same metastatic niches (endosteal and peri-vascular) indicating that both models are equally as useful for studying processes associated with early dissemination into bone but may be less useful for identifying mechanisms associated with bone homing ${ }^{[38]}$.

In breast cancer patients, it is believed that tumour cells at the primary site "prime" the bone for arrival of disseminating tumour cells, facilitating metastasis to this site ${ }^{[39]}$. This process is difficult to model in mice as human breast cancer cell lines rarely, if ever, spontaneously metastasise from the mammary fat pad to the mouse skeleton. Researchers have recently developed ER-positive and ER-negative models of spontaneous breast cancer metastasis to bone. In these models, injection of MCF7 or T47D cells into the fourth mammary fat pads results in spontaneous metastasis to mouse bone in $\sim 50 \%$ of animals ${ }^{[0,23,40]}$. In addition, injection of ER-positive BB3RC2 and BB2RC08 PDXs or ER-negative BB6RC37 PDXs into the fourth mammary duct using the MIND model also results in spontaneous metastasis to mouse bone in $32 \%, 20 \%$ and $20 \%$. respectively ${ }^{[23]}$. Interestingly, in all of these models, mice were supplemented with oestradiol to support tumour growth. In the MCF7 and T47D models, development of overt bone metastases was dependent on mice being supplemented with oestradiol, irrespective of the growth of the primary tumour; whether the same is true for these particular PDX models remains to be determined. Because oestradiol has profound bone anabolic effects, especially in mice [Figure 1], and can also alter anti-cancer immunity, supplementation with this hormone adds complexity to analysing results obtained using these model $\mathrm{s}^{[2,40]}$.

\section{(3) Breast cancer dormancy models}

As metastasis to mouse bone primarily occurs in young, 4 to 8-week-old animals or following oestradiol supplementation, it is hypothesised that high bone turnover is necessary to stimulate growth of human cancer cells in mouse bone. Researchers have used this idea to generate models in which manipulation of the bone environment can be used to investigate factors associated with breast cancer cell dormancy and metastatic outgrowth. Dissemination of MDA-MB-231 breast cancer cells into bone via intra-cardiac injection results in tumour cells lodging in the bone metastatic niche (primarily close to the growth plate in the trabecular region on bone $)^{[38,41]}$. In adult mice, metastatic outgrowth is rare, possibly due to low rates of bone turnover, leading researchers to hypothesise that older "adult" mice may provide a useful model for studying dormancy ${ }^{[42]}$. Labelling tumour cells with lipophilic membrane dyes, such as 1,1-Dioctadecyl3,3,3,3-tetramethylindodicarbocyanine (DiD) and 1,1'-Dioctadecyl-3,3,3',3'-Tetramethylindocarbocyanine Perchlorate (DiL), before intra-cardiac injection enables the researcher to differentiate between dormant and proliferating cancer cells in bone as the dyes are retained in the membrane of non-proliferating (dormant) cells but are progressively lost as cells go through subsequent rounds of proliferation ${ }^{[3,42,43]}$. Using DiD labelled MDA-MB-231 cells, researchers have demonstrated that in adult (14-16 weeks old) mice tumours lodge in the bone but remain dormant in this site with metastatic outgrowth occurring in $>10 \%$ of animals over the 84 -day time period tested ${ }^{[43]}$. Stimulating osteoclastic bone resorption by ovariectomy 
A

$1.7 \mathrm{mg}$ 17-B estradiol pellet

통

B

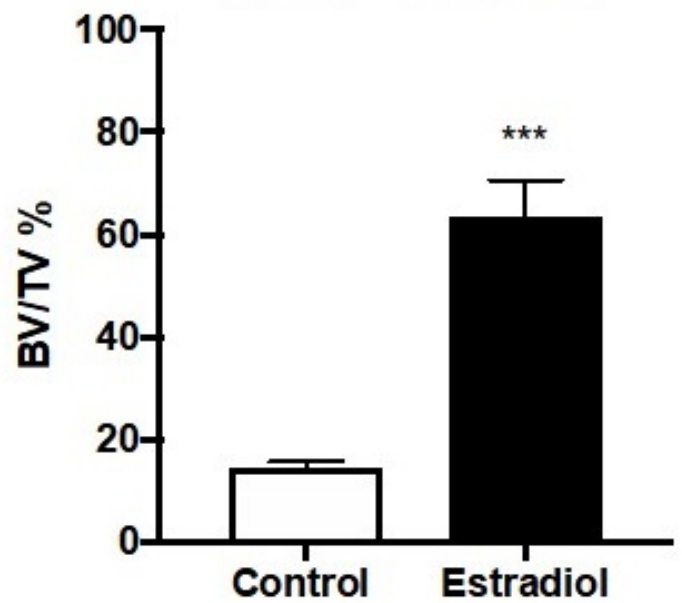

C

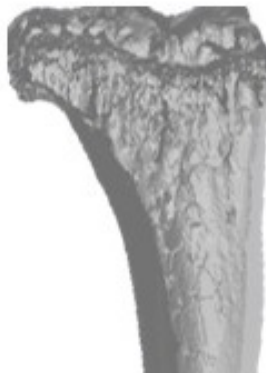

Control

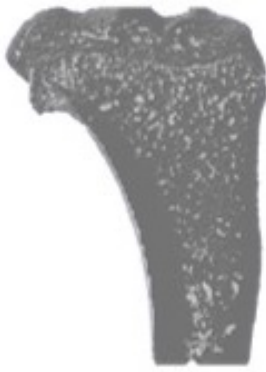

Estradiol
$12 \mathrm{mg} / \mathrm{L}$ 17-B estradiol via drinking water
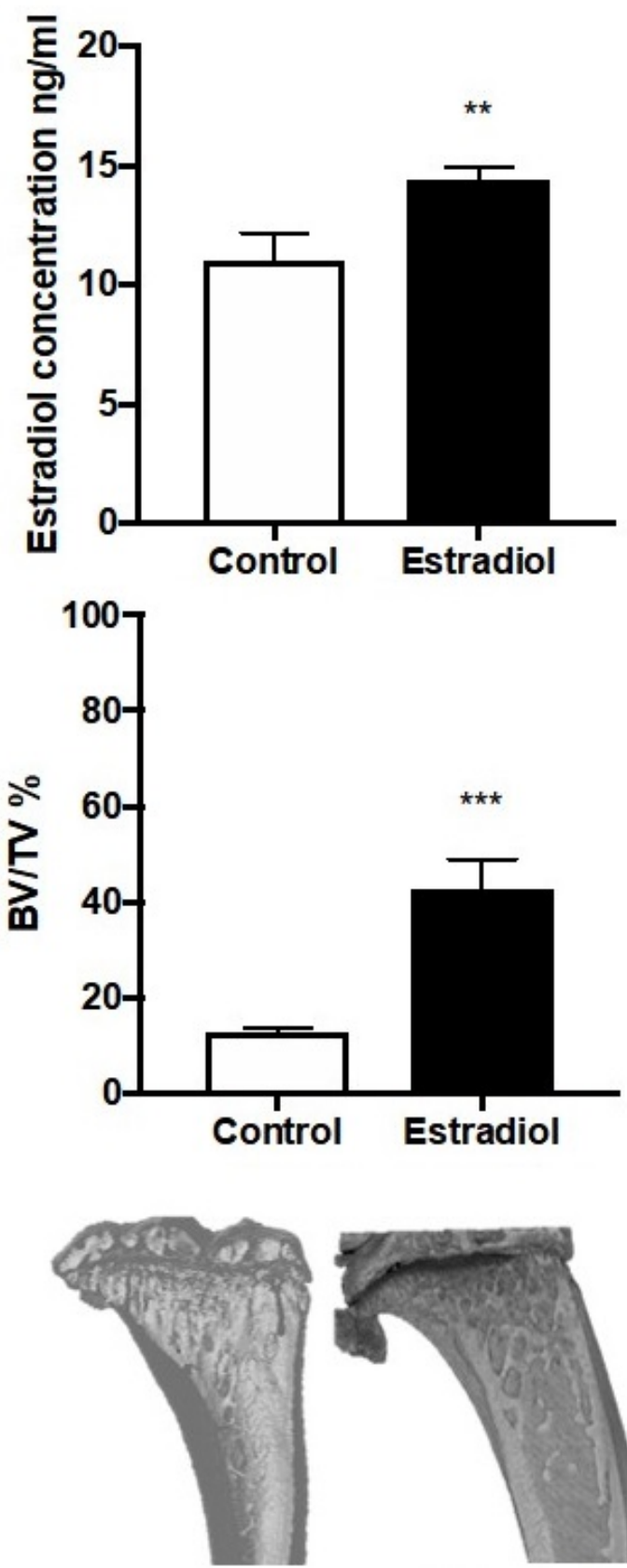

Control

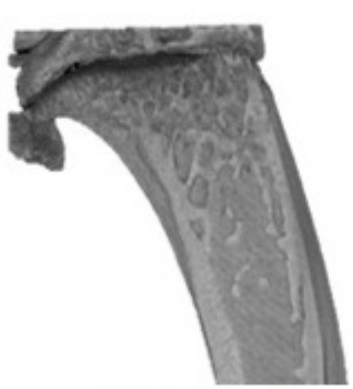

Estradiol

Figure 1. Effects of oestradiol on mouse tibiae. Eight-week-old $B A L B / c$ nu/nu mice received a 28-day release $1.7 \mathrm{mg} 17$ oestradiol pellet via subcutaneous implant or $12 \mathrm{mg} / \mathrm{L} 17$ oestradiol continually via their drinking water ( $n=10 /$ group). Mice were culled after 28 days and serum and tibiae isolated for analysis: (A) mean 4 SEM circulating concentrations of 17 oestradiol as measured by ELISA; (B) effects of 17 oestradiol on mean 4 SEM for percentage of trabecular bone volume compared with tissue volume (BV/TV\%) in the proximal tibiae; (C) representative, three-dimensional micro-CT images of tibiae from control (untreated) and 17 -treated tibiae. Statistical analysis was by student $t$-test. ${ }^{* \star} P<0.01$; ${ }^{* \star *} P<0.001$. Data shown are previously unpublished observations from the Ottewell laboratory.

results in development of overt metastases in $80 \%-90 \%$ of adult mice even after long-term dormancy ${ }^{[42,43]}$. 
There are currently no published data showing that this method of modelling metastatic dormancy/tumour outgrowth works for other breast cancer cell types. However, unpublished observations from the Ottewell lab suggest that ovariectomy can stimulate metastatic outgrowth tumour cells disseminated in bones of adult (14-16 weeks old) C57BL/6 mice following intra-ductal injection of E0771 cells (previously unpublished observations from the Ottewell laboratory; Figure 2), suggesting that ovariectomy may be a suitable method for modelling dormancy/tumour outgrowth in bone form a wider repertoire of cell lines.

\section{PDX models}

Breast cancer cell lines, which are commonly used to model bone metastasis including MDA-MB-231, MCF7 and T47D, have been in continuous culture, on plastic, in various laboratories for approximately 40 years $^{[44,45]}$. As a result, these cell lines have lost heterogeneity and no longer accurately represent the original tumour from which they were isolated. PDXs are tumours that have been cultured in immunecompromised whole body model systems immediately following surgical removal from the patient. These have not been cultured on plastic and for at least a minimal number of passages retain their original molecular sub-types and heterogeneity ${ }^{[46]}$. Thus, there is increasing interest in the use of PDXs to make more clinically relevant models of bone metastasis. Surgical implantation of dissociated PDXs into the cleared mammary fat pad or surgical engraftment of PDX fragments onto the existing mouse mammary fat pads results in tumour growth at the primary site and disseminated tumour cells in the bone marrow from both ER-negative breast cancers and a small number of ER-positive breast cancers ${ }^{[47-49]}$. However, outgrowth into overt metastases is very low (15\%) compared with development of metastasis in soft tissues such as ovaries, lung and liver which have been reported to be up to $100 \%, 40 \%$ and $20 \%$, respectively, from the same model ${ }^{[47]}$. Interestingly, metastatic outgrowth in bone has only been reported in one ER-negative PDX model without the use of oestradiol supplementation ${ }^{[4]}$. Injection of dissociated breast cancer PDXs into mice supplemented with oestradiol significantly increases occurrences of overt metastatic lesions. Injecting $\mathrm{ER}^{+} \mathrm{PR}^{+} \mathrm{HER} 2-\mathrm{PDXs}$ (BB3RC32 and BB2RC08) or ER-PR'HER2- PDXs (BB6RC37) into fourth mammary ducts of NSG mice, supplemented with oestradiol, resulted in spontaneous metastasis to bone in $75 \%, 20 \%$ and $20 \%$ of mice and metastasis to lung in $70 \%, 60 \%$ and $100 \%$ of mice, respectively ${ }^{[23]}$. Intracardiac injection of the same PDXs into NSG mice further increases overt bone metastases to $80 \%$ from $\mathrm{ER}^{+} \mathrm{PR}^{+} \mathrm{HER} 2$ BB3RC32 and BB2RC08 cells and 30\% from ERPR-HER2- BB6RC37 cells with lung metastases being detected in $40 \%, 80 \%$ and $100 \%$ of mice, respectively ${ }^{[23]}$. Taken together, these data support the idea that oestrogen stimulates development of overt metastases in bone, possibly through its anabolic actions, stimulating the bone metastatic niches, and both the seed (tumour cells) and soil (bone microenvironment) need to be optimal for metastases to develop in this organ.

\section{(1) Models of human breast cancer metastasis to human bone}

As discussed above, spontaneous metastasis of human breast cancer cells to mouse bone is rarely observed, especially in the absence of interventions that stimulate bone remodelling. Furthermore, strong evidence suggests a role for the metastatic niche in homing and colonisation of bone as well as regulating metastatic dormancy and growth (reviewed $\mathrm{in}^{[39,50]}$ ). It is possible that species differences may influence the ability of primary tumours to prime the metastatic niche for future arrival of tumour cells and/or regulate tumour cell dormancy/outgrowth in this metastatic site. To develop more clinically relevant models, in which human breast tumour cells metastasise to a tissue of human origin, researchers have developed mouse models in which pieces of human femoral bone are subcutaneously implanted into immunocompromised mice before injection of tumour cells ${ }^{[1,52]}$. Initial publications reported low rates of metastasis to the human bone implants from a number of cell lines injected via tail vein or orthotopic implantation, and osteotropism was only reported from the SUM1315 breast cancer cell line $\mathrm{e}^{[51]}$. 


\section{A 3- weeks following intra-ductal injection of $2 \times 10^{5}$ E0771 cells}
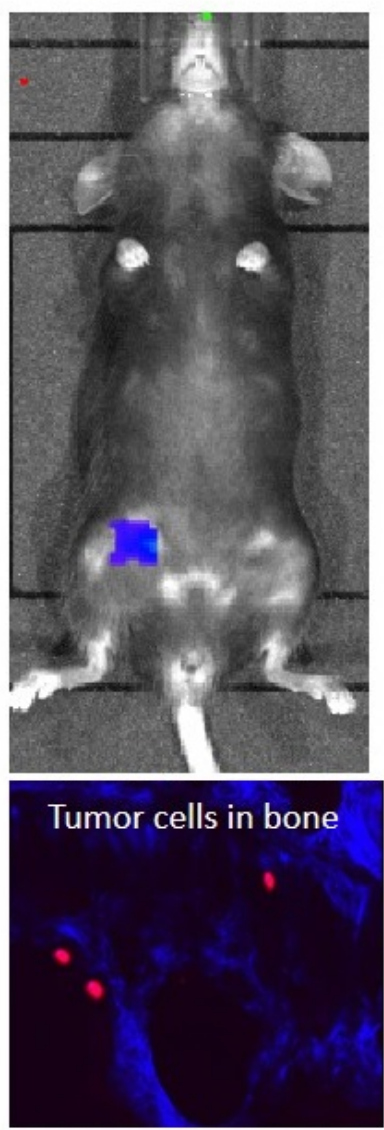

\section{B 5-weeks following intra-ductal injection of $2 \times 10^{5}$ E0771 cells and 2 weeks after ovariectomy}
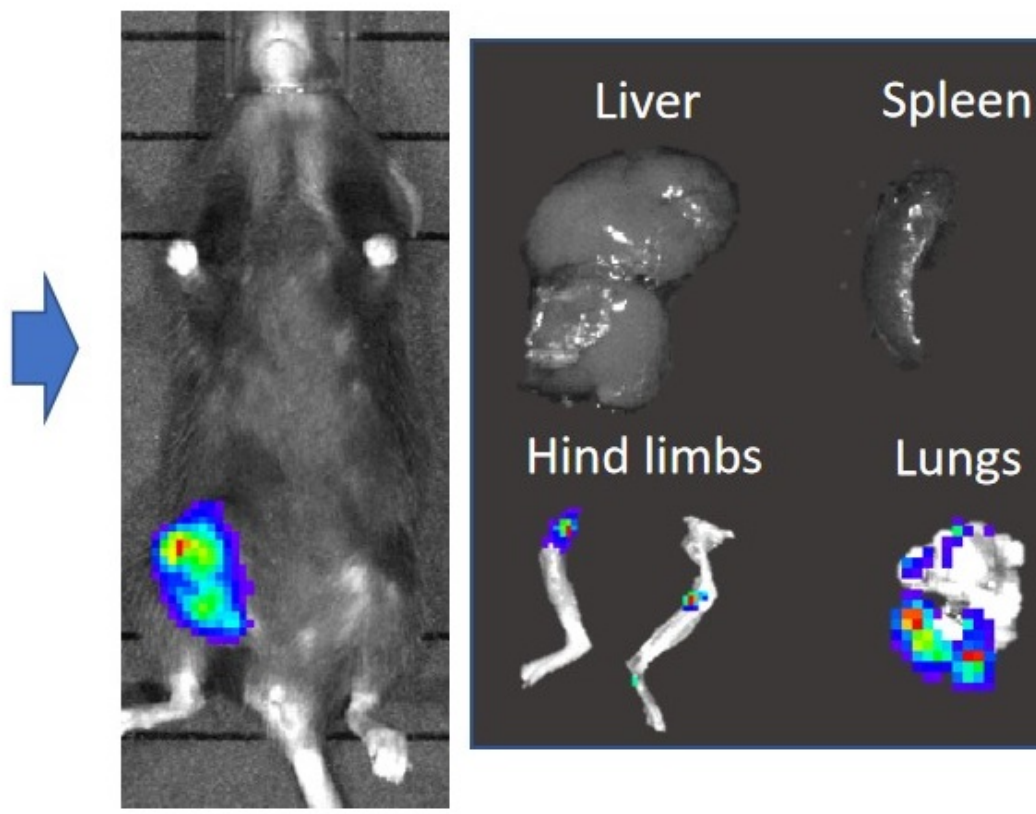

\section{Hind limbs}

Lungs

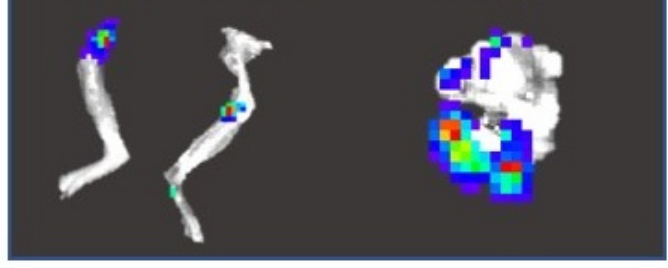

Figure 2. Ovariectomy stimulates metastatic outgrowth of E0771 mammary cancer cells disseminated in bones of syngeneic C57BL/6 mice. Injection of $2 \times 10^{5}$ E0771 cells into the fourth mammary duct of 12-week-old female C57BL/6 mice resulted in tumour growth at the primary site and dissemination of tumour cells into the skeleton (A). Five weeks following ovariectomy, disseminated tumour cells in bone were activated to induce overt metastases. These metastatic outgrowths can be observed in the ling bones and lungs (B). Data shown are previously unpublished observations from the Ottewell laboratory.

Recent refinements to these human-to-human model systems have led to significant improvements in metastasis rates from both ER-positive and ER-negative breast cancers: the sub-chondral portion of femoral bone shows increased biological activity compared with spongy bone ${ }^{[53]}$, and haematopoiesis is retained in this tissue following implantation into NOD SCID mice ${ }^{[23]}$. Selectively implanting sub-chondral bone increases spontaneous metastasis of MDA-MB-231 cells from the mammary fat pad to human bone implants by $40 \%{ }^{[23]}$. Using the mammary intraductal (MIND) method to inject tumour cells directly into the fourth mammary ducts further increases metastasis rates to $\sim 70 \%{ }^{[23]}$. Using these optimised conditions, metastasis from the primary site to human bone could also be detected in 40\%-50\% mice injected with ERpositive MCF7 or T47D breast cancer cells, 100\% of mice injected with ER-positive BB3RC32 or BB2RC08 PDXs and $20 \%$ of mice injected with ER-negative BB6RC37 PDXs [Table 1] ${ }^{[23]}$. Interestingly, PDXs also metastasised to human bone implants following intra-cardiac injection (80\% from BB3RC32, 80\% from $\mathrm{BB} 2 \mathrm{RC} 08$ and 30\% from BB6RC27). Importantly, bone metastases have been shown to be more prevalent from ER-positive PDXs compared with ER-negative, with ER-negative preferentially metastasising to lung, which is in line with predicted metastasis patterns observed in breast cancer patients; no lung metastases have been observed from breast cancer cell lines ${ }^{[23]}$. When analysing data generated using these models, 
several factors should be taken into account: simultaneous to injection of PDXs and ER-positive cell lines, mice were supplemented with oestradiol, and, although these cell types predominantly metastasised to human bone implants, metastasis to mouse bone was also detected. Oestradiol supplementation is not required for metastasis of ER-negative, MDA-MB-231 or SUM1315 cells, and these specifically spread to the human bone implants ${ }^{[23]}$. As oestradiol has been shown to stimulate ER-positive tumour metastasis to mouse bone ${ }^{[23,40]}$, it is possible that this apparent tropism to mouse bone, seen in PDXs or ER-positive cell lines in this model, is influenced by this hormone, and this hypothesis is supported by work carried out by Yang et al. ${ }^{[54]}$. Using a similar model, in which non-tumour bearing human bone and human bone impregnated with MDA-MB-231-GFP breast cancer cells were implanted into opposite flanks of NOD SCID mice, tumour cells were found to spontaneously metastasise from the original bone metastases, specifically, to the contralateral non-tumour bearing human bone implant ${ }^{[54]}$. Similarly, the same research group showed that two out of five human primary tumour samples co-implanted with human bone were able to grow in this bone ( $\mathrm{HuP} 2$, a metaplastic carcinoma, and $\mathrm{HuP}_{4}$, a ductal carcinoma); despite both of these tumours growing to $2-3 \mathrm{~cm}$ in diameter in the human bone grafts, metastasis to the contralateral non-tumour bearing human bone implants was only detected from $\mathrm{HuP} 4$. Interestingly, mice used in this study were not supplemented with oestradiol and metastasis to mouse bone was not observed. It must be noted, however, that metastases in the contralateral human bones were small (only detectable microscopically), and whether lack of metastasis to mouse bone is due to no tumours cells being disseminated in this site or metastases being too small to detect remains to be established. In this manuscript, the authors hypothesise that this apparent lack of metastasis to mouse bone is indicative of species specificity and that this model can be used to decipher between metastatic and non-metastatic breast cancer; however, as only one patient sample was metastatic, more data are required for these types of conclusion to be drawn ${ }^{[52]}$. These human bone models necessitate the use of immune-compromised mice; despite implanted bone demonstrating active haematopoiesis and production of human B cells, the lack of autoimmunity observed in these models suggests that human immune cells are not very active, and the presence of human $\mathrm{T}$ cells has not yet been investigated ${ }^{[2,51]}$. It is apparent that, although data from mouse models of human breast cancer metastasis to human bone implants are amassing, further research is required before we can explore the full potential of these models.

For experiments designed to determine the latter stages of bone metastasis in a human-specific environment, tumour cells can be seeded directly into subchondral bone discs of various sizes. These cocultures can subsequently be used for in vitro assays or can be implanted into NOD SCID mice for investigating parameters associated with tumour cell-bone cell interactions ${ }^{[53]}$. Importantly, molecular profiling performed in both the spontaneous metastasis and co-culture implant models has identified novel signaling pathways that have subsequently been confirmed to be clinically relevant in the bone metastatic $\operatorname{process}^{[6]}$.

It should be noted that the use of human-specific models for research purposes are not a simple option. These models require appropriate ethical agreements to be in place as well as access to freshly resected femoral heads that need to be sectioned and implanted into mice/placed in culture within $2-3 \mathrm{~h}$ following surgical resection. Furthermore, to achieve consistent data, bone samples should be cut to a standard size; this accuracy necessitates the use of specialised equipment (as described $\mathrm{in}^{[23,53]}$ ). For researchers wishing to model the entire metastatic process from tumour growth in the mammary site to overt metastases in bone, this is lengthy and expensive. Tumour cells are injected four weeks following implantation of human bone, and, dependent on the tumour cells being tested, it can take a further 6-15 weeks before metastases are detected in this metastatic site [Table 1]. Injecting PDXs requires additional expansion of the tumour cells in NSG mice prior to implantation to ensure sufficient numbers of cells from the same patient are available 
for experimental purposes, further adding time and expense to these experiments. Therefore, although human-to-human bone metastasis models provide useful, clinically relevant tools for investigating tumour cell-bone cell interactions and the metastatic process in a human-specific environment, their use is unlikely to supersede the cheaper, more commonly used intra-cardiac injection models of metastases to mouse bone.

\section{Immune competent models}

\section{Transgenic models}

Modelling breast cancer bone metastasis in immunocompetent models enables the researcher to assess how the immune system interacts with various stages of the metastatic process as well as interactions with anticancer agents. Although there are multiple transgenic models in which genetic manipulation of genes including P53, TGFa, Myc, Wnt1, $\beta$-Catenin, NOTCH4, Cox2 ErbB-1 (neu) and SV40 results in spontaneously develop mammary cancers, from which metastasis to lung is commonplace, spontaneous metastasis to bone appears to be an extremely rare event and is almost never reported in the literature (reviewed $\mathrm{in}^{[55]}$ ). A possible exception to this is a transgenic mouse deficient in $p 53$ and E-Cadherin in the mammary gland ${ }^{[56]}$. This $W c r e ; C d k 1^{F / F} ; \operatorname{Tr} p 53^{F / F}$ mouse shows pleomorphic similarities to the invasive lobular carcinoma seen in humans. Multifocal tumours spontaneously develop in $\sim 74 \%$ of mice in several mammary glands, and, although the majority of mammary cells from these mice are ER-negative, occasional weak expression of ER was identified in low-grade tumours with ER status being inversely correlated to tumour stage. In this model, female mice whose primary tumours reached $\sim 1 \mathrm{~cm}$ in diameter presented with extensive local invasion and metastasis to draining lymph nodes. Metastases were also detected in the skin, lungs, liver, gastrointestinal tract, pancreas and spleen. Interestingly, the authors also reported bone metastasis from several $W c r e ; C d k 1^{F / F} ; \operatorname{Trp} 53^{F / F}$ mice; however, no indications of metastatic frequency or duration to detection of tumour cells in this site were reported, making it difficult to establish the usefulness of this model for studying bone metastasis per $s e^{[56]}$.

\section{Syngeneic models}

Because bone metastases are rare from transgenic models, researchers have developed syngeneic models in which mouse mammary cancer cells are injected into recipient mice of a complementary background to those in which the cells were originally generated. These syngeneic models, however, do not permit use of human breast cancer cells or PDX. As the aetiologies of human and mouse mammary cancer metastases differ fundamentally, in that human breast cancer primarily metastasises to bone, whereas mouse mammary cancer preferentially metastasises to lung and almost never to bone, data from these models should be interpreted accordingly. These low rates of spontaneous bone metastasis may, in part, be due to biological differences between humans and mice: mouse cells have enhanced metabolic activity and longer telomerases compared to human cells, influencing oncogenesis and phenotypic differences ${ }^{[57]}$. Mammary tumours also develop from different cell lineages with mouse tumours originating from mesenchymal tissue and human tumours arising primarily from epithelial cell $s^{[57]}$. In addition, mouse mammary tumours are hormone independent, whereas the majority of human tumours that metastasise to bone are hormone responsive requiring higher concentrations of oestrogen to support their growth ${ }^{[58]}$.

To address the issue of low rates of bone metastasis, researchers have produced bone trophic sublines of mouse mammary cancer cells via repeated in vivo passaging through bone. Orthotopic injection of some of these cell lines results in spontaneous metastasis to the mouse skeleton to varying degrees ( $20 \%$ from $4 \mathrm{~T} 1$ cells, 40\%-60\% from $4 \mathrm{~T} 1-2,50 \%$ from KEP and 60\%-80\% from E0771) $)^{[6,33,59,60]}$. Primary tumours grow rapidly in these models and often need to be surgically removed to allow time for metastatic outgrowth to be detected in bone. Because all of these syngeneic cell lines also spontaneously metastases to lung and the lung metastases develop more rapidly than the bone metastases, bone metastatic deposits are often very small and difficult to detect on histological sections, complicating downstream analysis. 
Increased bone metastases rates and sizes can be achieved by introducing these cell lines via intra-cardiac injection. Osteolytic bone metastases can be detected in 70\%-90\% of mice following injection of 4T1-2, E0771 or Py8119 cells into the left cardiac ventricle, however lung and other soft tissue metastases are still prevalent in all of these model systems ${ }^{[60-62]}$. It therefore appears that the only way to model bone metastases in syngeneic model systems, without the complications associated with soft tissue metastases, is to inject tumour cells directly into the long bones (tibia/femur). Injecting mouse mammary cancer cells into their complementary mouse model results in high engraftment rates (up to 100\%) and provides a useful tool for modelling tumour cell-bone cell interactions in an immune competent environment ${ }^{[60,61,63]}$.

\section{ASSESSMENT OF TUMOUR PROGRESSION IN BONE Imaging in live animals}

To enable analysis of tumour progression at the primary site and/or in bone in live animals, cell lines/PDXs are commonly pre-labelled with luciferase or fluorescent proteins before injection. Fluorescently-labelled tumours [Figures 2 and $3 \mathrm{~A}]^{[36]}$ can be detected by placing the mouse under a light source and visualising through the correct filters using a simple machine such as a LightTools box. This method is cheap, quick and easy to use; however, the data are not quantifiable, and skeletal tumours can be difficult to observe until they are very large due to autofluorescence from the bone and light scatter. Bioluminescent imaging is much more sensitive, and tumours in bone can be detected using this method before they are visible on histological sections. This method therefore allows longitudinal, real time imaging studies of metastases development in bone. Importantly, data obtained from bioluminescence readouts ${ }^{[6,42,43]}$ from tumours using a luminomior such an IVIS system are quantifiable, making this the preferred analytical method.

In addition to tumour growth, researchers are often interested in the effects that tumours and/or treatments are having on the bone microenvironment. Osteolytic lesion area and abnormal bone remodelling can be visualised and assessed weekly in vivo using a cabinet X-ray machine or by live $\mu \mathrm{CT}$ imaging of the affected bone(s) [Figure $3 \mathrm{~B}]^{[18,42,43,64]}$. Using in vivo $\mu \mathrm{CT}$ scanning, percentage changes in trabecular bone parameters and the size or number of osteolytic lesions can be measured over time as bone disease develops [Figure $4 \mathrm{~A}-\mathrm{C}$ ]. In addition, following bone modulating therapy, effects on bone repair (new bone formation and bone density) can be mapped by overlaying bone images from the same mouse at different time points, as previously described ${ }^{[65,66]}$.

\section{Post-mortem analysis of bone metastases}

With the exception of metastases from PDXs, bone lesions develop rapidly in mice, and animals should be monitored daily for changes in activity levels, mobility and onset of cachexia. For humane endpoint, mice should be euthanised before $20 \%$ body weight is lost, tumour progression impairs mobility or an animal appears to be in respiratory distress, taking into consideration local guidelines/approvals. To ensure that data obtained from experiments are comparable between groups, mice should be culled on the same day so that the experimental timeframe is standardised, the exception being for experiments designed to assess survival.

On termination of the experiment, mice should be examined closely for evidence of metastatic foci outside of bone. For studies in which tumour cells have been introduced via intra-cardiac injection, researchers should check accuracy of their technique before determining which mice should be selected for downstream analysis. For all tumour cell types, growth in the mediastinum surrounding the heart indicates that cells were not accurately injected into the left cardiac ventricle, and, specifically for MDA-MB-231 cells, tumour growth in the lungs suggests mis-injection into the right cardiac ventricle, from which bone metastases will not develop. Mice in which these mis-injections are detected should be excluded from the study. On 
A In vivo imaging of tumour growth in bone

I)

Bioluminescent imaging

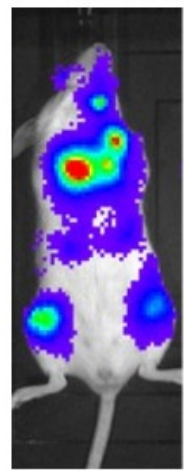

$B A L B / C$

$\mathrm{BALB} / \mathrm{c}$ nu/nu

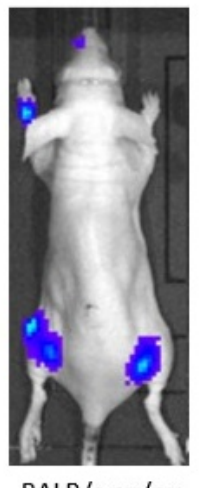

II)

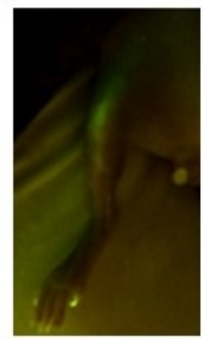

$\mathrm{BALB} / \mathrm{c} \mathrm{nu} / \mathrm{nu}$

Whole leg
Fluorescent imaging

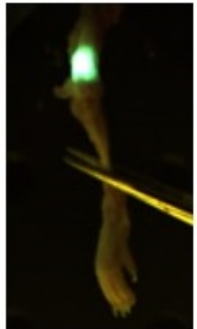

Following removal of skin
I)

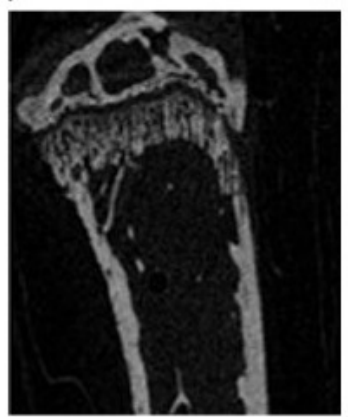

Longitudinal section
uCT

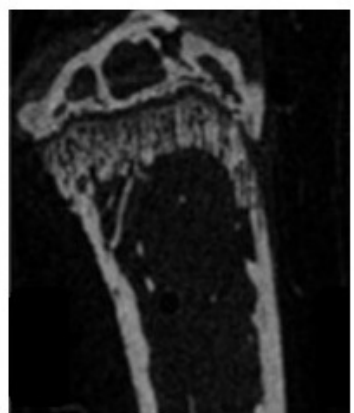

Cross section

C Histological analysis of tumour growth in bone

I)

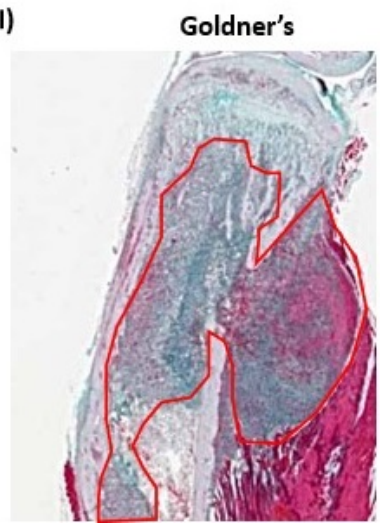

II) H\&E
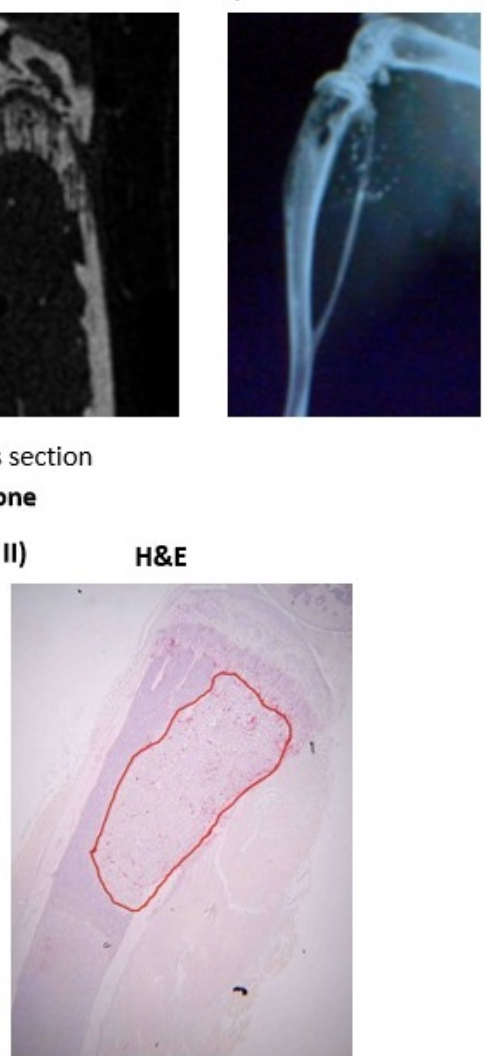

Figure 3. Common analysis of mouse models of bone metastases. In total, $1 \times 10^{5} 4 \mathrm{~T} 1$ or $5 \times 10^{5} \mathrm{MDA}-\mathrm{MB}-231$ cells were injected into $B A L B / C$ or $B A L B / C$ nude mice, respectively. $B A L B / C$ mice were imaged two weeks after tumour cell injection and $B A L B / C$ nude mice imaged four weeks after tumour cell injection. Mice were culled for downstream analysis $24 \mathrm{~h}$ after imaging. (A) Bioluminescence imaging of tumours in the skeleton of $B A L B / C$ and $B A L B / c$ nude mice by IVIS (I) and florescence imaging of MDA-MB-231 tumours in the tibia of a $B A L B / C$ nude mouse by LightTools ${ }^{T M}$. (B) Two-cross sections of longitudinal and cross-sectional micro-CT images (I) and whole leg X-ray images of tumour bearing bones from $B A L B / c n u / n u$ mice. (C) Two-dimensional $3 \times M$ histological sections of tumour bearing tibiae from $B A L B / C$ mice following staining with Goldner's trichrome (I) and $H \& E$ (II); tumour in bone is highlighted with a red outline. Data shown are previously unpublished images from the Ottewell laboratory.

dissection, all skeletal muscle from the forelimbs, hind limbs and vertebral column should be removed prior to downstream processing. Bone can then be flash frozen in liquid $\mathrm{N}_{2}$ for RNA/protein extraction or 
A In vivo micro-CT Scanning of a mouse tibia.

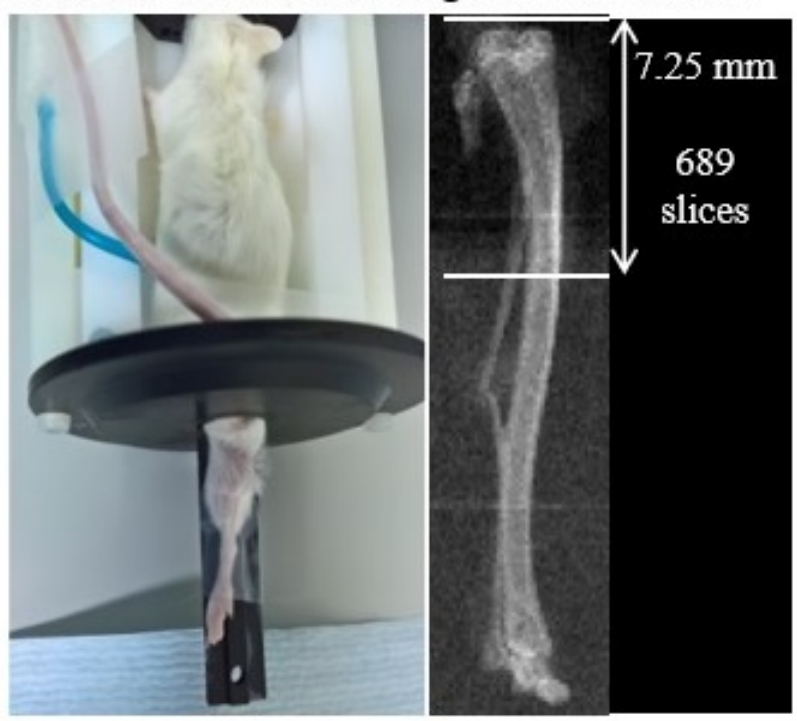

B In vivo micro-CT analyses of scanned tibia.

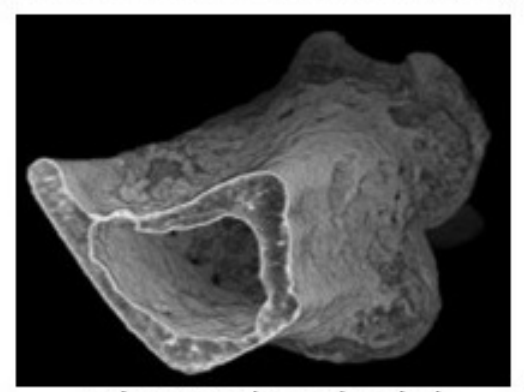

Volume rendering (Drishti)

C Example of In vivo micro-CT images over time after tumour injection (6-10 weeks) and changes to bone structure (development of osteolytic lesions) in a single mouse .

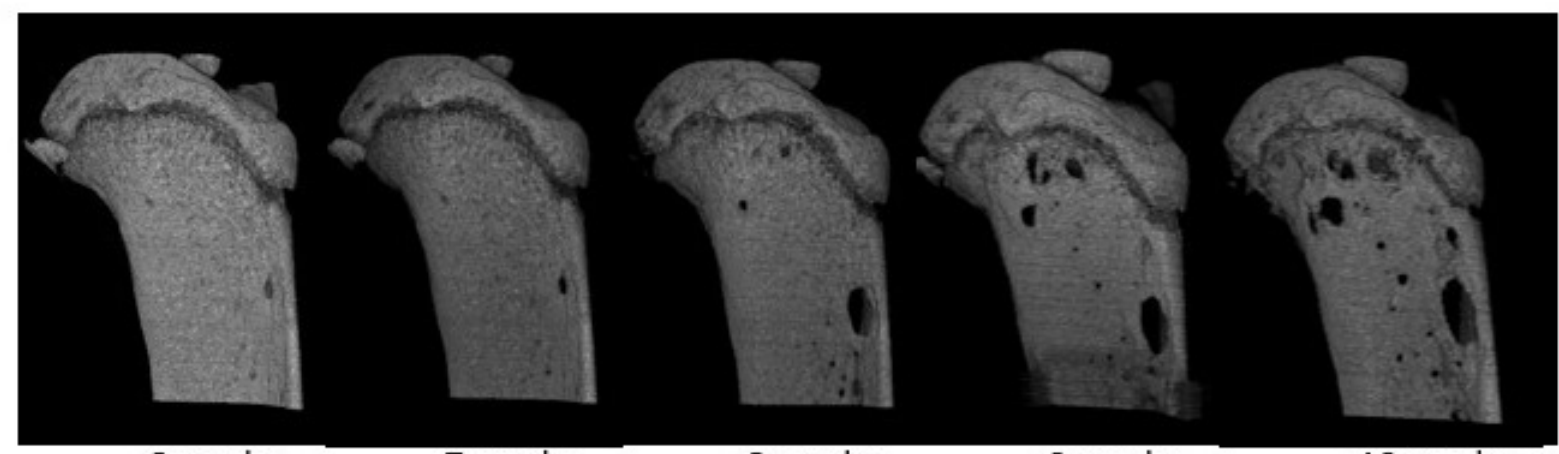

6 weeks

7 weeks

8 weeks

9 weeks

10 weeks

Figure 4. In vivo $\times$ CT scanning to monitor cancer-induced bone disease development over time: (A) in vivo micro-CT scanner set up and area measured of a mouse right tibia; (B) in vivo micro-CT image analyses of a scanned right tibia using Drishti and ImageJ; and (C) representative in vivo micro-CT images of right tibiae from the same mouse over time (6-10 weeks post tumour cell injection) showing the development of osteolytic lesions. Data shown are previously unpublished images from the Lawson laboratory.

downstream analysis of dormant, DiD-labelled tumour cells in bone prior to storing at $-80{ }^{\circ} \mathrm{C}$ [Figure $1 \mathrm{~A}]^{[38,42,43]}$. Alternatively, skeletal samples can be fixed for histology in $4 \%$ paraformaldehyde for $24-$ 
$48 \mathrm{~h}$. At this point, ex vivo $\mu \mathrm{CT}$ can be used to measure effects on trabecular and cortical bone [Figure $3 \mathrm{~B}$ ] before being decalcified in a solution of $1 \%$ PFA/0.5\% EDTA for two weeks (changing the solution daily).

For histological analysis, decalcified paraffin-embedded bone is usually cut longitudinally into 3-5 $\mu \mathrm{m}$ sections and stained with haematoxylin-eosin (H\&E) or Goldner's trichrome [Figure 3C], and tumour burden is measured using an image analysis software package. H\&E sections are also useful for measuring the number of cuboidal-shaped osteoblasts lining the bone. Osteoclast number and surface area of osteoclasts in contact with bone can be scored following visualisation with tartrate resistant acid phosphatase stain. It is also possible to carry out immunohistochemistry/immunofluorescence for a number of other molecular targets in histological sections of paraffin embedded and frozen sections of bone metastases, enabling researchers to investigate expression profiles of proteins that are of particular interest ${ }^{[19,30,53,6]}$. Additionally, serum can be assayed for the presence of bone turnover markers (such as TRAP5c for osteoclast activity and P1NP for osteoblast activity), hormones (oestrogen, inhibin, etc.), inflammatory factors or growth factors of interest. Methodologies for all of these routine procedures are described in detail in the following references ${ }^{[6,16,18,19,36,42,43]}$.

\section{DISCUSSION}

The development of bone metastasis from breast cancer requires tumour cells to spontaneously develop at the primary site; secrete factors that prime bone for the arrival of tumour cells in this site ${ }^{[3,4,6,64]}$; undergo epithelial to mesenchymal transition ${ }^{[6]}$; disseminate into the circulation; extravasate in bone; home to the bone metastatic niche ${ }^{[7,8]}$; undergo a period of dormancy ${ }^{[10]}$; interact with the bone microenvironment to reduce anti-tumour immune regulation and expand the niches ${ }^{[7,8,68]}$; and grow in the bone forming osteolytic or mixed lesions ${ }^{[11-13]}$. Whilst we have excellent immune compromised models for investigating how human tumour cells colonise bone and interact with the bone microenvironment during the formation of metastases, including homing to the metastatic niche, metastatic dormancy and tumour outgrowth, these models primarily rely on human ER-negative, MDA-MB-231 cells, which exclusively form osteolytic lesions in bone ${ }^{[19,30,42,43]}$. The majority of human breast cancers that metastasise to bone are ER-positive, and, although human ER+ve MCF7 and T47D cells do metastasise to bone forming mixed lesions, to stimulate growth in a non-human environment, mice receive oestradiol supplementation, altering the bone microenvironment and making data difficult to interpret ${ }^{[40]}$. There is speculation amongst the research community that MCF7 and T47D cells will grow in mouse bone in the absence of oestradiol over extended time periods, possibly $>6$ months. Further research is required to test this hypothesis as an ER-positive model of human breast cancer with long-term dormancy in bone would be highly reflective of human disease and may prove useful in increasing our understanding of dormancy/metastatic outgrowth. There are currently no immune competent models that allow us to investigate effects of immune regulation of metastasis from human breast cancer. With the advent of immunotherapies and increased appreciation of the importance of immune regulation in the metastatic process, researchers have put extensive efforts into producing an increasing library of syngeneic mouse models including bone homing variants of mouse $4 \mathrm{~T} 1$, E0771 and Py8119 cells $s^{[6,60-62,68]}$. These models can be used to investigate lytic disease (4T1 and E0771) and mixed lesions (Py8119; unpublished observations from the Ottewell laboratory) and are generating exciting new data demonstrating the fundamental roles of the immune system in the regulation of bone metastasis that cannot be generated in immune-compromised mice ${ }^{[61,68]}$. However, as discussed above, it must be noted that there are fundamental differences between human and mouse breast cancers, as well as the human and mouse bone microenvironments ${ }^{[57,58]}$. Furthermore, mice do not express the same complement of immune cells subsets as humans ${ }^{[2]}$, therefore data from these model systems cannot be interpreted independently and confirmatory experiments need to be performed in human samples. Currently, the most clinically relevant models appear to be those in which human PDXs spontaneously metastasise from the mammary gland to 
human bone implants; these models allow the investigation of the growth of heterogeneous patient samples from different tumour subtypes and their ability to metastasise and interact with a human bone environment in a mouse with a semi-competent human immune system ${ }^{[2,52,54]}$. These models, however, are far from perfect and are expensive and difficult to run. It is unclear how active the human B cells are in this model and whether any other human immune cell subsets are present; further work is required to establish this. A mouse model of human breast cancer to human bone metastasis with a fully competent immune system would be a highly relevant tool. Extensive work has been carried out by various research groups to make mouse models with a human-specific immune system for research purposes. In these models, NSG mice are irradiated prior to injection of human haematopoietic stem cells; the resulting mice have been successfully used to show effects of immunotherapies in various cancer types including breast cancer ${ }^{[69-71]}$. It would be interesting to see if the same process could be used to produce a mouse model of human breast cancer metastasis to human bone with a competent human immune system and whether this would be possible given the difficulties of obtaining all three samples (bone, primary tumour and haematopoietic stem cells) from the same donor to avoid auto immunity.

In conclusion, there is a large array of mouse model systems available to researchers for investigating various parameters associated with breast cancer bone metastasis. When used in combination, these model systems cover most aspects associated with the metastatic process including growth at the primary site, spontaneous spread to bone, homing to the metastatic niche, dormancy and metastatic outgrowth. Models are also available to investigate the effects of immune cells on these processes. However, to date, there is not one model system that covers all of the processes, and there are no systems which reliably model spontaneous development of the primary tumour followed by bone metastasis. Researchers must therefore select the most appropriate model system(s) for their research question and interpret their data accordingly, giving special consideration to the need for experiments to be performed either with multiple cell lines or in multiple systems before reliable conclusions can be made.

\section{DECLARATIONS}

\section{Authors' contributions}

Wrote the manuscript and provided data for Figures 1-3: Ottewell PD

Edited the manuscript and provided text and data for Figure 4: Lawson MA

\section{Availability of data and materials}

Not applicable.

\section{Financial support and sponsorship}

None.

\section{Conflicts of interest}

All authors declared that there are no conflicts of interest.

\section{Ethical approval and consent to participate}

Not applicable.

\section{Consent for publication}

Not applicable. 


\section{Copyright}

(C) The Author(s) 2021.

\section{REFERENCES}

1. Salvador F, Llorente A, Gomis RR. From latency to overt bone metastasis in breast cancer: potential for treatment and prevention. $J$ Pathol 2019;249:6-18. DOI PubMed PMC

2. George CN, Canuas-Landero V, Theodoulou E, Muthana M, Wilson C, Ottewell P. Oestrogen and zoledronic acid driven changes to the bone and immune environments: Potential mechanisms underlying the differential anti-tumour effects of zoledronic acid in preand post-menopausal conditions. J Bone Oncol 2020;25:100317. DOI PubMed PMC

3. Ma L, Teruya-Feldstein J, Weinberg RA. Tumour invasion and metastasis initiated by microRNA-10b in breast cancer. Nature 2007;449:682-8. DOI PubMed

4. Huang Q, Gumireddy K, Schrier M, et al. The microRNAs miR-373 and miR-520c promote tumour invasion and metastasis. Nat Cell Biol 2008;10:202-10. DOI PubMed

5. Cox TR, Rumney RMH, Schoof EM, et al. The hypoxic cancer secretome induces pre-metastatic bone lesions through lysyl oxidase. Nature 2015;522:106-10. DOI PubMed PMC

6. Tulotta C, Lefley DV, Freeman K, et al. Endogenous Production of IL1B by Breast Cancer Cells Drives Metastasis and Colonization of the Bone Microenvironment. Clin Cancer Res 2019;25:2769-82. DOI PubMed

7. Massagué J, Obenauf AC. Metastatic colonization by circulating tumour cells. Nature 2016;529:298-306. DOI PubMed PMC

8. Weilbaecher KN, Guise TA, McCauley LK. Cancer to bone: a fatal attraction. Nat Rev Cancer 2011;11:411-25. DOI PubMed PMC

9. Hess KR, Pusztai L, Buzdar AU, Hortobagyi GN. Estrogen Receptors and Distinct Patterns of Breast Cancer Relapse. Breast Cancer Res Treat 2003;78:105-18. DOI PubMed

10. Goss PE, Chambers AF. Does tumour dormancy offer a therapeutic target? Nat Rev Cancer 2010;10:871-7. DOI PubMed

11. Tahara RK, Brewer TM, Theriault RL, Ueno NT. Bone Metastasis of Breast Cancer. In: Ahmad A, editor. Breast Cancer Metastasis and Drug Resistance. Cham: Springer International Publishing; 2019. pp. 105-29.

12. Owen KL, Parker BS. Beyond the vicious cycle: The role of innate osteoimmunity, automimicry and tumor-inherent changes in dictating bone metastasis. Mol Immunol 2019;110:57-68. DOI PubMed

13. Ottewell PD. The role of osteoblasts in bone metastasis. J Bone Oncol 2016;5:124-7. DOI PubMed PMC

14. Heilmann T, Rumpf AL, Roscher M, et al. Dasatinib prevents skeletal metastasis of osteotropic MDA-MB-231 cells in a xenograft mouse model. Arch Gynecol Obstet 2020;301:1493-502. DOI PubMed

15. Bellahcène A, Bachelier R, Detry C, Lidereau R, Clézardin P, Castronovo V. Transcriptome analysis reveals an osteoblast-like phenotype for human osteotropic breast cancer cells. Breast Cancer Res Treat 2007;101:135-48. DOI PubMed

16. Eyre R, Alférez DG, Santiago-Gómez A, et al. Microenvironmental IL1 $\beta$ promotes breast cancer metastatic colonisation in the bone via activation of Wnt signalling. Nat Commun 2019;10:5016. DOI PubMed PMC

17. Tulotta C, Groenewoud A, Snaar-jagalska BE, Ottewell P. Animal Models of Breast Cancer Bone Metastasis. In: Idris AI, editor. Bone Research Protocols. New York: Springer; 2019. pp. 309-30.

18. Ottewell PD, Deux B, Mönkkönen H, et al. Differential effect of doxorubicin and zoledronic acid on intraosseous versus extraosseous breast tumor growth in vivo. Clin Cancer Res 2008;14:4658-66. DOI PubMed

19. Nutter F, Holen I, Brown HK, et al. Different molecular profiles are associated with breast cancer cell homing compared with colonisation of bone: evidence using a novel bone-seeking cell line. Endocr Relat Cancer 2014;21:327-41. DOI PubMed

20. Reed ND, Manning DD. Long-term maintenance of normal human skin on congenitally athymic (nude) mice. Proc Soc Exp Biol Med 1973;143:350-3. DOI PubMed

21. Zhang X, Lewis MT. Establishment of Patient-Derived Xenograft (PDX) Models of Human Breast Cancer. Curr Protoc Mouse Biol 2013;3:21-9. DOI PubMed

22. Kanaya N, Somlo G, Wu J, et al. Characterization of patient-derived tumor xenografts (PDXs) as models for estrogen receptor positive (ER+HER2- and ER+HER2+) breast cancers. J Steroid Biochem Mol Biol 2017;170:65-74. DOI PubMed PMC

23. Lefley D, Howard F, Arshad F, et al. Development of clinically relevant in vivo metastasis models using human bone discs and breast cancer patient-derived xenografts. Breast Cancer Res 2019;21:130. DOI PubMed PMC

24. Okada S, Vaeteewoottacharn K, Kariya R. Application of Highly Immunocompromised Mice for the Establishment of Patient-Derived Xenograft (PDX) Models. Cells 2019;8:889. DOI PubMed PMC

25. Han Y, Nakayama J, Hayashi Y, et al. Establishment and characterization of highly osteolytic luminal breast cancer cell lines by intracaudal arterial injection. Genes Cells 2020;25:111-23. DOI PubMed

26. Yi B, Williams PJ, Niewolna M, Wang Y, Yoneda T. Tumor-derived platelet-derived growth factor-BB plays a critical role in osteosclerotic bone metastasis in an animal model of human breast cancer. Cancer Res 2002;62:917-23. PubMed

27. Isoda T, BaBa S, Maruoka Y, et al. Influence of the Different Primary Cancers and Different Types of Bone Metastasis on the Lesionbased Artificial Neural Network Value Calculated by a Computer-aided Diagnostic System, BONENAVI, on Bone Scintigraphy Images. Asia Ocean J Nucl Med Biol 2017;5:49-55. DOI PubMed PMC

28. Tamura D, Hiraga T, Myoui A, Yoshikawa H, Yoneda T. Cadherin-11-mediated interactions with bone marrow stromal/osteoblastic cells support selective colonization of breast cancer cells in bone. Int J Oncol 2008;33:17-24. PubMed

29. Pécheur I, Peyruchaud O, Serre CM, et al. Integrin alpha(v)beta3 expression confers on tumor cells a greater propensity to metastasize to bone. FASEB J 2002;16:1266-8. DOI PubMed 
30. Kang Y, Siegel PM, Shu W, et al. A multigenic program mediating breast cancer metastasis to bone. Cancer Cell 2003;3:537-49. DOI PubMed

31. Wetterwald A, van der Pluijm G, Que I, et al. Optical Imaging of Cancer Metastasis to Bone Marrow. Am J Pathol 2002;160:1143-53. DOI PubMed PMC

32. Bishop RT, Marino S, Carrasco G, et al. Combined administration of a small-molecule inhibitor of TRAF6 and Docetaxel reduces breast cancer skeletal metastasis and osteolysis. Cancer Lett 2020;488:27-39. DOI PubMed

33. Bishop RT, Marino S, de Ridder D, et al. Pharmacological inhibition of the IKKE/TBK-1 axis potentiates the anti-tumour and antimetastatic effects of Docetaxel in mouse models of breast cancer. Cancer Lett 2019;450:76-87. DOI PubMed

34. Fathers KE, Bell ES, Rajadurai CV, et al. Crk adaptor proteins act as key signaling integrators for breast tumorigenesis. Breast Cancer Res 2012;14:R74. DOI PubMed PMC

35. Werbeck JL, Thudi NK, Martin CK, et al. Tumor microenvironment regulates metastasis and metastasis genes of mouse MMTVPymT mammary cancer cells in vivo. Vet Pathol 2014;51:868-81. DOI PubMed PMC

36. Ottewell PD, Woodward JK, Lefley DV, Evans CA, Coleman RE, Holen I. Anticancer mechanisms of doxorubicin and zoledronic acid in breast cancer tumor growth in bone. Mol Cancer Ther 2009;8:2821-32. DOI PubMed

37. Zhou Y, Shao G, Liu S. Monitoring Breast Tumor Lung Metastasis by U-SPECT-II/CT with an Integrin $\alpha(\mathrm{v}) \beta(3)$-Targeted Radiotracer( 99m)Tc-3P-RGD(2). Theranostics 2012;2:577-88. DOI PubMed PMC

38. Allocca G, Hughes R, Wang N, et al. The bone metastasis niche in breast cancer-potential overlap with the haematopoietic stem cell niche in vivo. J Bone Oncol 2019;17:100244. DOI PubMed PMC

39. Peinado H, Zhang H, Matei IR, et al. Pre-metastatic niches: organ-specific homes for metastases. Nat Rev Cancer 2017;17:302-17. DOI PubMed

40. Holen I, Walker M, Nutter F, et al. Oestrogen receptor positive breast cancer metastasis to bone: inhibition by targeting the bone microenvironment in vivo. Clin Exp Metastasis 2016;33:211-24. DOI PubMed

41. Wang N, Reeves KJ, Brown HK, et al. The frequency of osteolytic bone metastasis is determined by conditions of the soil, not the number of seeds; evidence from in vivo models of breast and prostate cancer. J Exp Clin Cancer Res 2015;34:124. DOI PubMed PMC

42. Ottewell PD, Wang N, Brown HK, et al. Zoledronic acid has differential antitumor activity in the pre- and postmenopausal bone microenvironment in vivo. Clin Cancer Res 2014;20:2922-32. DOI PubMed PMC

43. Ottewell PD, Wang N, Brown HK, et al. OPG-Fc inhibits ovariectomy-induced growth of disseminated breast cancer cells in bone. Int J Cancer 2015;137:968-77. DOI PubMed

44. Cailleau R, Young R, Olivé M, Reeves WJ Jr. Breast tumor cell lines from pleural effusions. J Natl Cancer Inst 1974;53:661-74. DOI PubMed PMC

45. Sher E, Eisman JA, Moseley JM, Martin TJ. Whole-cell uptake and nuclear localization of 1,25-dihydroxycholecalciferol by breast cancer cells (T47 D) in culture. Biochem J 1981;200:315-20. DOI PubMed PMC

46. Lv X, Dobrolecki LE, Ding Y, Rosen JM, Lewis MT, Chen X. Orthotopic Transplantation of Breast Tumors as Preclinical Models for Breast Cancer. J Vis Exp 2020;(159):10.3791/61173. DOI PubMed PMC

47. Fatima I, El-Ayachi I, Playa HC, et al. Simultaneous Multi-Organ Metastases from Chemo-Resistant Triple-Negative Breast Cancer Are Prevented by Interfering with WNT-Signaling. Cancers (Basel) 2019;11:2039. DOI PubMed PMC

48. Giuliano M, Herrera S, Christiny P, et al. Circulating and disseminated tumor cells from breast cancer patient-derived xenograftbearing mice as a novel model to study metastasis. Breast Cancer Res 2015;17:3. DOI PubMed PMC

49. Pillai SG, Li S, Siddappa CM, Ellis MJ, Watson MA, Aft R. Identifying biomarkers of breast cancer micrometastatic disease in bone marrow using a patient-derived xenograft mouse model. Breast Cancer Res 2018;20:2. DOI PubMed PMC

50. Zhang W, Bado I, Wang H, Lo HC, Zhang XH. Bone Metastasis: Find Your Niche and Fit in. Trends Cancer 2019;5:95-110. DOI PubMed PMC

51. Kuperwasser C, Dessain S, Bierbaum BE, et al. A mouse model of human breast cancer metastasis to human bone. Cancer Res 2005;65:6130-8. DOI PubMed

52. Lam P, Yang W, Amemiya Y, et al. A human bone NOD/SCID mouse model to distinguish metastatic potential in primary breast cancers. Cancer Biol Ther 2009;8:1010-7. DOI PubMed

53. Holen I, Nutter F, Wilkinson JM, Evans CA, Avgoustou P, Ottewell PD. Human breast cancer bone metastasis in vitro and in vivo: a novel 3D model system for studies of tumour cell-bone cell interactions. Clin Exp Metastasis 2015;32:689-702. DOI PubMed

54. Yang W, Lam P, Kitching R, et al. Breast cancer metastasis in a human bone NOD/SCID mouse model. Cancer Biol Ther 2007;6:1289-94. DOI PubMed

55. Ottewell PD, Coleman RE, Holen I. From genetic abnormality to metastases: murine models of breast cancer and their use in the development of anticancer therapies. Breast Cancer Res Treat 2006;96:101-13. DOI PubMed

56. Derksen PW, Braumuller TM, van der Burg E, et al. Mammary-specific inactivation of E-cadherin and p53 impairs functional gland development and leads to pleomorphic invasive lobular carcinoma in mice. Dis Model Mech 2011;4:347-58. DOI PubMed PMC

57. Céspedes MV, Casanova I, Parreño M, Mangues R. Mouse models in oncogenesis and cancer therapy. Clin Transl Oncol 2006;8:31829. DOI PubMed

58. Nandi S, Guzman RC, Yang J. Hormones and mammary carcinogenesis in mice, rats, and humans: a unifying hypothesis. Proc Natl Acad Sci U S A 1995;92:3650-7. DOI PubMed PMC

59. Buijs JT, Matula KM, Cheung H, et al. Spontaneous bone metastases in a preclinical orthotopic model of invasive lobular carcinoma; the effect of pharmacological targeting TGF $\beta$ receptor I kinase. J Pathol 2015;235:745-59. DOI PubMed PMC 
60. Pulaski BA, Ostrand-Rosenberg S. Mouse 4T1 breast tumor model. Curr Protoc Immunol 2001; Chapter 20:Unit 20.2. DOI PubMed

61. Tulotta CM, Lefley DV, Amariutei AE, et al. Inhibition of breast cancer bone metastasis through Interleukin-1B regulated tumourassociated innate immune response. Breast Cancer Res Treat 2020;180:538-9.

62. Hiraga T, Ninomiya T. Establishment and characterization of a C57BL/6 mouse model of bone metastasis of breast cancer. $J$ Bone Miner Metab 2019;37:235-42. DOI PubMed

63. Zhou JZ, Riquelme MA, Gao X, Ellies LG, Sun LZ, Jiang JX. Differential impact of adenosine nucleotides released by osteocytes on breast cancer growth and bone metastasis. Oncogene 2015;34:1831-42. DOI PubMed PMC

64. Cox TC. Microcomputed tomography of craniofacial mineralized tissue: A practical user's guide to study planning and generating quality data. Bone 2020;137:115408. DOI PubMed

65. Green AC, Lath D, Hudson K, et al. TGF $\beta$ Inhibition Stimulates Collagen Maturation to Enhance Bone Repair and Fracture Resistance in a Murine Myeloma Model. J Bone Miner Res 2019;34:2311-26. DOI PubMed

66. Paton-Hough J, Tazzyman S, Evans H, et al. Preventing and Repairing Myeloma Bone Disease by Combining Conventional Antiresorptive Treatment With a Bone Anabolic Agent in Murine Models. J Bone Miner Res 2019;34:783-96. DOI PubMed PMC

67. Westbrook JA, Cairns DA, Peng J, et al. CAPG and GIPC1: Breast Cancer Biomarkers for Bone Metastasis Development and Treatment. J Natl Cancer Inst 2016:108. DOI PubMed PMC

68. Monteran L, Ershaid N, Sabah I, et al. Bone metastasis is associated with acquisition of mesenchymal phenotype and immune suppression in a model of spontaneous breast cancer metastasis. Sci Rep 2020;10:13838. DOI PubMed PMC

69. Yao L, Aryee K, Cheng M, Kaur P, Keck JG, Brehm MA. Creation of PDX-Bearing Humanized Mice to Study Immuno-oncology. In: Moll J, Carotta S, editors. Target Identification and Validation in Drug Discovery. New York: Springer; 2019. pp. 241-52. DOI PubMed

70. Hasgur S, Aryee KE, Shultz LD, Greiner DL, Brehm MA. Generation of Immunodeficient Mice Bearing Human Immune Systems by the Engraftment of Hematopoietic Stem Cells. In: Proetzel G, Wiles MV, editors. Mouse Models for Drug Discovery. New York: Springer; 2016. pp. 67-78. DOI PubMed PMC

71. Wege AK, Ernst W, Eckl J, et al. Humanized tumor mice-a new model to study and manipulate the immune response in advanced cancer therapy. Int J Cancer 2011;129:2194-206. DOI PubMed 